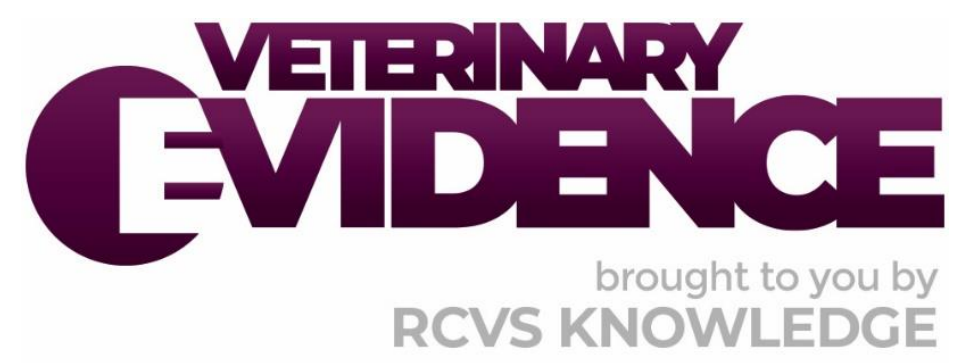

\title{
In Greyhounds with paw pad corns, is surgical excision more effective at resolving lameness than extirpation?
}

\author{
A Knowledge Summary by
}

Dan Kenny BVSC MRCVS ${ }^{*}$

\footnotetext{
${ }^{1}$ Paragon Veterinary Referrals, Red Hall Crescent, Wakefield, West Yorkshire, WF1 2DF

* Corresponding Author (dan-kenny@hotmail.co.uk)
}

ISSN: 2396-9776

Published: 03 Sep 2020

in: The Veterinary Evidence journal Vol 5, Issue 3

DOI: $\underline{10.18849 / V E . V 5 I 3.316}$

Reviewed by: Robert Pettitt (BVSc PGCertLTHE DSAS (Orth) SFHEA FRCVS) and Stephen Jones (MVB MS DACVS)

Next Review Date: 22 Nov 2021 


\section{PICO question}

In Greyhounds (and Sighthounds) with recurring pedal corns, is surgical excision in comparison to corn extirpation more effective at resolving lameness?

\section{Clinical bottom line}

\section{Category of research question}

\section{Treatment}

\section{The number and type of study designs reviewed}

Three case series were included, all three were retrospective, one included a prospective component. There was one opinion-based narrative review and one opinion-based article.

\section{Strength of evidence}

Weak

\section{Outcomes reported}

Extirpation allows only a short palliation of lameness and repeated treatment is required at variable intervals. Surgical excision may provide good rates of short-term resolution however, in the long-term recurrence rates are still moderate. It should also be born in mind that further corns may develop in different digits.

\section{Conclusion}

In Greyhounds (and Sighthounds) with recurring pedal corns, surgical excision of the corn is more likely to provide long-term resolution of lameness in comparison to extirpation. However, the current level of evidence on this topic is weak.

\section{How to apply this evidence in practice}

The application of evidence into practice should take into account multiple factors, not limited to: individual clinical expertise, patient's circumstances and owners' values, country, location or clinic where you work, the individual case in front of you, the availability of therapies and resources.

Knowledge Summaries are a resource to help reinforce or inform decision-making. They do not override the responsibility or judgement of the practitioner to do what is best for the animal in their care.

\section{Clinical Scenario}

A 9-year-old ex-racing Greyhound presents with a 3 week history of right thoracic limb lameness which worsens when walking on hard surfaces. The dog has a firm well circumscribed, circular lesion on the pad surface of digit three of the right thoracic limb which is painful on palpation. You suspect that the lesion is a corn however you have never treated one before. You can recall that a previous colleague used to manage them by hulling them out with a dental elevator, your current colleagues suggest surgical excision of the lesion. As you have never treated this condition before you decide to look for higher level evidence. 


\section{The evidence}

There is limited evidence to suggest that one technique is superior to the other with regards to outcome as none of the cited studies directly compare these techniques. All cited studies are either opinion pieces or case series with no statistical analysis performed and are therefore low on the hierarchy of evidence.

\section{Summary of the evidence}

\begin{tabular}{|c|c|}
\hline \multicolumn{2}{|l|}{ Görtz et al. (2003) } \\
\hline Population: & $\begin{array}{l}\text { Dogs with focal circular hyperkeratosis (paw pad corns). } \\
\text { Case 1: 6-year-old Whippet with bilateral lesions on digit four of the } \\
\text { thoracic limbs. } \\
\text { Case 2: } 6 \text {-year-old Whippet with lesions on digit three and four right } \\
\text { thoracic limb. } \\
\text { Case 3: } 5 \text {-year-old Greyhound with lesions on digital pads three and } \\
\text { four of the right thoracic limb. }\end{array}$ \\
\hline Sample size: & 3 dogs \\
\hline Intervention details: & $\begin{array}{l}\text { - Case 1: Deep surgical excision of the lesions with } 8 \mathrm{~mm} \text { punch } \\
\text { biopsy and wounds dressed and treated with paw wax. } \\
\text { - Case 2: Deep surgical excision and paw wax bandage. } \\
\text { - Case 3: Superficial excision performed. }\end{array}$ \\
\hline Study design: & Retrospective case series \\
\hline Outcome studied: & Resolution of lesion and lameness, recurrence of lesion and lameness. \\
\hline $\begin{array}{l}\text { Main findings: } \\
\text { (relevant to PICO question): }\end{array}$ & $\begin{array}{l}\text { - Deep surgical excision provided short- to long-term resolution } \\
\text { of the lesions based on follow-up at } 4 \text { months and } 5 \text { years. } \\
\circ \text { Case 1: No recurrence } 4 \text { months post-surgery. } \\
\text { Case 2: The dog was euthanised for unrelated reasons } 5 \\
\text { years later with no recurrence of the lesion. } \\
\text { - Superficial excision provided very short-term resolution (1 } \\
\text { week to } 5 \text { months); repeated excision was required to manage } \\
\text { recurrence. } \\
\text { Case 3: } 18 \text { day post-surgery another lesion believed to be } \\
\text { a corn developed on the left thoracic limb. Repeated } \\
\text { superficial excision was performed, initially weekly then at } \\
5 \text { monthly intervals. In the meantime, the dog was } \\
\text { symptom free. }\end{array}$ \\
\hline Limitations: & $\begin{array}{l}\text { - Case series and therefore low on hierarchy of evidence. } \\
\text { - Retrospective series. } \\
\text { - Low number of cases. } \\
\text { - Limited follow-up length in one case (4 months), recurrence } \\
\text { may have occurred after this point. } \\
\text { - Case history details regarding treatment are very brief in } \\
\text { some cases. }\end{array}$ \\
\hline
\end{tabular}




\begin{tabular}{|l|l|}
\hline - & Only two cases had a histopathological diagnosis suggestive of \\
& the lesion being a corn (Case 1 and Case 3). Case 2 did not \\
& have histopathological analysis performed. Although the \\
& lesion had the gross appearance of a corn, without \\
& histopathology it is possible that this case was misdiagnosed. \\
- & No details of superficial excision technique were available. \\
\hline
\end{tabular}

\begin{tabular}{|c|c|}
\hline \multicolumn{2}{|l|}{ Macherey \& Feeman (2006) } \\
\hline Population: & Dogs with paw pad corns \\
\hline Sample size: & Not applicable \\
\hline Intervention details: & Extirpation of corn using dental root elevator \\
\hline Study design: & $\begin{array}{l}\text { Narrative review article with opinion-based outline of corn extirpation } \\
\text { technique }\end{array}$ \\
\hline Outcome studied: & Resolution of lesion and lameness, recurrence of lesion and lameness \\
\hline $\begin{array}{l}\text { Main findings: } \\
\text { (relevant to PICO question): }\end{array}$ & $\begin{array}{l}\text { - Extirpation (or 'hulling') of corns can improve lameness. } \\
\text { - Extirpation can be relatively simple and is frequently } \\
\text { - } \text { performed without requirement for sedation. } \\
\text { - Recurrence can occur in as little as } 3 \text { weeks. }\end{array}$ \\
\hline Limitations: & $\begin{array}{l}\text { - This is an opinion-based article which is at the bottom of the } \\
\text { hierarchy of evidence. } \\
\text { - There is no scientific data to support conclusions for this } \\
\text { technique. }\end{array}$ \\
\hline
\end{tabular}

\begin{tabular}{|c|c|}
\hline Population: & Dogs with paw pad corns (single and multiple) \\
\hline Sample size: & 24 dogs (18 Greyhounds) \\
\hline Intervention details: & $\begin{array}{l}\text { - Surgical excision or debridement, topical application of tea } \\
\text { tree oil or other ointments, application of duct tape and use } \\
\text { of padded boots. } \\
\text { - Histologic analysis and immunohistochemical staining and } \\
\text { polymerase chain reaction (PCR) for papilloma virus. Of the } 11 \\
\text { biopsy specimens available, six were from greyhounds and } \\
\text { five were from non-greyhound dogs. None of the greyhounds } \\
\text { were positive for papilloma virus on immunohistochemical } \\
\text { staining, whereas } 3 / 5 \text { non-Greyhound dogs tested positive for } \\
\text { papilloma virus. For these three lesions results of PCR were } \\
\text { suggestive of a previously undiagnosed strain of papilloma } \\
\text { virus, two lesions had histological evidence of viral inclusion } \\
\text { bodies. }\end{array}$ \\
\hline
\end{tabular}




\begin{tabular}{|c|c|}
\hline Study design: & Retrospective case series \\
\hline Outcome studied: & $\begin{array}{l}\text { - Histologic and immunohistochemical staining and PCR for } \\
\text { papilloma virus. } \\
\text { - Recurrence of lesion. }\end{array}$ \\
\hline $\begin{array}{l}\text { Main findings: } \\
\text { (relevant to PICO question): }\end{array}$ & $\begin{array}{l}\text { - Owners of } 17 / 24 \text { ( } 71 \%) \text { dogs including } 11 / 18(61 \%) \\
\text { Greyhounds were contacted by telephone to obtain follow-up } \\
\text { information. } \\
\text { - One Greyhound was euthanised for unrelated reasons } 6 \\
\text { months post-surgical excision with no recurrence at this time. } \\
\text { - The remaining } 10 / 18 \text { ( } 55 \%) \text { had recurrence of the original } \\
\text { lesions or developed new lesions either on the same digit or } \\
\text { on a different digit or paw. All } 10 \text { owners reported some } \\
\text { degree of distress related to the dogs' level of discomfort. } \\
\text { Two owners had considered euthanasia because of concerns } \\
\text { over their dogs' welfare. } \\
\text { - The remaining } 6 / 24 \text { ( } 22 \%) \text { dogs with available follow-up were } \\
\text { all non-Greyhounds with a single lesion in which surgical } \\
\text { excision was reportedly curative. } \\
\text { This may suggest differing aetiology between Greyhounds and } \\
\text { other breeds. }\end{array}$ \\
\hline Limitations: & $\begin{array}{l}\text { - Main objective of study was to determine clinical, histologic } \\
\text { and immunohistochemical findings with wart-like lesions } \\
\text { involving the paw pads and was not an assessment of } \\
\text { treatment success. } \\
\text { - Outcome was not recorded or matched to treatment type, so } \\
\text { it is unknown how many of these patients were surgically } \\
\text { managed and how well they did. } \\
\text { - Lack of objective follow-up data. Outcome was based on } \\
\text { - owner perception via telephone conversation. } \\
\text { - The study-up time was not defined. } \\
\text { - The study was retrospective and therefore subject to } \\
\text { evidence. } \\
\text { The sample size was small. }\end{array}$ \\
\hline
\end{tabular}

Balara et al. (2009b)

\begin{tabular}{|r|l|}
\hline Population: & Dogs with paw pad corns \\
\hline Sample size: & Not applicable \\
\hline Intervention details: & $\begin{array}{l}\text { Surgical excision of single lesions with a } 2 \text { week follow-up of splint or } \\
\text { soft padded bandaging. }\end{array}$ \\
\hline Study design: & Opinion piece - letter to author, author response. \\
\hline
\end{tabular}




\begin{tabular}{|c|c|}
\hline Outcome studied: & Not applicable \\
\hline $\begin{array}{l}\text { Main findings: } \\
\text { (relevant to PICO question): }\end{array}$ & $\begin{array}{l}\text { - Author acknowledges that extirpation of corns can be } \\
\text { associated with temporary reduction in pain and lameness. } \\
\text { However, given the suspected mechanical aetiology, } \\
\text { recurrence is inevitable. } \\
\text { - Author recommends surgical excision of single lesions, } \\
\text { followed by } 2 \text { weeks of splinting or soft bandaging of the limb. } \\
\text { - Surgical excision is not recommended in dogs with multiple } \\
\text { lesions. }\end{array}$ \\
\hline Limitations: & $\begin{array}{l}\text { - This is an opinion-based article and therefore at the bottom of } \\
\text { the hierarchy of evidence. } \\
\text { - There is no scientific evidence put forward to support these } \\
\text { recommendations. }\end{array}$ \\
\hline
\end{tabular}

\begin{tabular}{|c|c|}
\hline \multicolumn{2}{|l|}{ Guilliard et al. (2010) } \\
\hline Population: & Dogs with paw pad corns (single or multiple) \\
\hline Sample size: & $\begin{array}{l}30 \text { dogs ( } 13 \text { retrospective and } 17 \text { prospective cases). Seven dogs had } \\
\text { multiple corns making a total of } 40 \text { corns. }\end{array}$ \\
\hline Intervention details: & $\begin{array}{l}\text { Primary treatment: } \\
\text { Surgical excision ( } 27 \text { dogs, } 34 \text { corns): An elliptical incision was } \\
\text { made through the dermis around the corn, the corn was then } \\
\text { dissected from underlying connective tissues. The pad was } \\
\text { sutured using simple interrupted sutures placed away from } \\
\text { the margins of the incisions. The foot was then bandaged. This } \\
\text { was changed at weekly intervals for } 3 \text { weeks when sutures } \\
\text { were removed. } \\
\text { Distal digital ostectomy (three dogs, three corns): Involving } \\
\text { removal of the distal condyles of the second phalanx with any } \\
\text { remaining bone and nail of the third phalanx. The pad was } \\
\text { sutured on its dorsal aspect over the stump of the second } \\
\text { phalanx. A full thickness oval skin incision was made just } \\
\text { caudal to the palmar/plantar aspect of the pad and closed in } \\
\text { order to prevent the pad from rotating dorsally. Corn excision } \\
\text { was performed if the corn would still be left on the weight- } \\
\text { bearing part of the pad after reconstruction. } \\
\text { No treatment (two dogs, three corns): These lesions did not } \\
\text { elicit pain on digital pressure and were considered } \\
\text { asymptomatic. } \\
\text { Follow-up: } 1 \text { year - } 5 \text { years }\end{array}$ \\
\hline Study design: & Case series ( 4 year retrospective and 2 year prospective components) \\
\hline Outcome studied: & Resolution of lameness and recurrence of lameness and lesion. \\
\hline
\end{tabular}




\begin{tabular}{|c|c|}
\hline $\begin{array}{l}\text { Main findings: } \\
\text { (relevant to PICO question): }\end{array}$ & $\begin{array}{l}\text { Dogs undergoing surgical excision ( } 27 \text { dogs, } 34 \text { corns): } \\
\text { - } 1 / 27 \text { ( } 3.7 \% \text { ) dogs lameness remained unchanged, } 2 / 27 \text { ( } 7.4 \%) \\
\text { had reduced lameness and } 11 / 27 \text { ( } 40.7 \% \text { ) had recurrence of } \\
\text { lameness. } \\
\text { - } \quad 3 / 27 \text { ( } 11 \%) \text { dogs (four corns) had the surgical procedure } \\
\text { repeated due to recurrence. } \\
\text { - The resolution rate following subsequent surgery is unknown. } \\
\text { - Reported short-term outcome (up to } 1 \text { year): } 20 / 27 \text { (74\%) of } \\
\text { dogs had resolution of lameness. } \\
\text { - Reported long-term outcome (up to } 5 \text { years): } 14 / 27 \text { (52\%) } \\
\text { dogs had a recurrence of lameness due to corn regrowth. } \\
\text { Dogs undergoing distal digital ostectomy (three dogs, three corns): } \\
\text { - No recurrence of lameness, in two cases the corn was not } \\
\text { removed, and it resolved on its own accord. }\end{array}$ \\
\hline Limitations: & $\begin{array}{l}\text { - } \text { Case series so descriptive study type. } \\
\text { - } \text { evidence. } \\
\text { - } \quad \text { Now number of dogs in distal digital ostectomy group. } \\
\text { methods could be made. } \\
\text { - Complete individual patient follow-up unknown. } \\
\text { - The number of corns per dog in the results is unclear at times } \\
\text { which renders the results and outcomes difficult to interpret } \\
\text { in places. } \\
\text { - True recurrence rate following surgical excision is likely higher } \\
\text { as the minimum follow-up was } 1 \text { year and a recurrence was } \\
\text { only noted if the dog became lame. } \\
\text { - Concomitant injuries were present in some cases (such as } \\
\text { carpal hyperextension, P2/3 luxation or ankylosis and deep } \\
\text { digital flexor tendon (DDFT)/superficial digital flexor tendon } \\
\text { (SDFT) injury) which may affect outcome measures. } \\
\text { One dog was found to have a plant based foreign body at } \\
\text { histopathology and one dog was found to have a radiopaque } \\
\text { foreign body (grit) at radiography which was surgically } \\
\text { removed. These differing aetiologies may affect treatment } \\
\text { outcome. } \\
\text { - Subjective measurement of lameness. } \\
\text { - Home follow-up was by telephone which relies on owner } \\
\text { assessment of lameness. } \\
\text { (three cases seen subsequent to closure of the study). } \\
\text { Otherwise diagnosis was based on appearance only. }\end{array}$ \\
\hline
\end{tabular}


Numerous treatments have been described for digital pad corns in Sighthounds but currently none of these appear to result in a predictable and satisfactory long-term resolution of lameness. Two of the most commonly used treatment methods in veterinary practice are extirpation ('hulling') or deep surgical excision of the lesions. Extirpation involves removing the hard, central core of the corn. An instrument such as a dental elevator is used to work around the junction of the hard centre of the corn and the soft tissue of the pad. A twisting or rocking motion is used to separate the lateral edges of the corn from the pad. Once the sides are free, the base of the corn is released by angling the instrument parallel to the footpad surface at the base of the corn, scissors may be required to remove any remaining attachment. There should be no pain or bleeding. Surgical excision of a whole corn involves making an incision through the dermis around the periphery of the corn. This can be performed with a scalpel blade or punch biopsy instrument. The underlying soft tissues are then dissected away, and the corn removed. The pad is sutured, and the foot can be placed in a protective dressing.

There are no studies directly comparing these two techniques so papers assessing individual techniques were reviewed. The only article to discuss extirpation or hulling of corns in relative detail, described the use of a dental elevator to remove corns in conscious dogs. Although the author reports that lameness initially improves, recurrence was reported to occur in as little as 3 weeks post-procedure (Macherey \& Feeman, 2006). Unfortunately, this article was a narrative review and stated outcomes were not supported with scientific evidence. Case 3 in the case series by Görtz et al. (2003) underwent superficial excision of corns which may also refer to a procedure similar to the extirpation described by Macherey \& Feeman (2006). The details of the procedure, however, were not available making this conclusion impossible to draw.

Surgical excision was the treatment modality used in two papers for which the outcomes were recorded (Görtz et al., 2003; and Guilliard et al., 2010). No recurrence was reported at 4 months and 5 years post-surgical excision of corns in two Whippets (Görtz et al., 2003). Guilliard et al. (2010) reported a 1 year success rate of $74 \%$ in surgically excised corns but in the long-term, up to 5 years, $52 \%$ had regrowth of the lesions. Out of 27 dogs which had initial surgical excision one dog remained lame, two dogs had improved lameness and 11 dogs had recurrence of lameness. Three dogs had the procedure repeated once and one dog had the procedure repeated four times at a mean period of 20 months between surgeries. Balara et al. (2009a) reported that $10 / 18(55 \%)$ Greyhounds with corns treated in the study had recurrence of the original lesion or developed novel lesions. Unfortunately, the treatment modality was not linked to recurrence as an outcome measure and therefore it is impossible to ascertain what rate of recurrence was present amongst dogs treated by debridement or by deep surgical excision. However, in an opinion-based article the authors of this study recommend that single corns are treated by surgical excision with postoperative splinting or bandaging, they also acknowledge that although extirpation can be associated with reduction or resolution of lameness, recurrence is inevitable (Balara et al., 2009b).

Retrospective case series, case reports and opinion articles are very low on the hierarchy of evidence therefore drawing accurate conclusions regarding the superiority of either technique is challenging. The highest level of evidence regarding extirpation is based on opinion and regarding surgical excision, although the evidence is of a higher level, it is scarce and generally retrospective. It is clear that there is requirement for higher level evidence and studies involving larger number of dogs to accurately assess the two treatment modalities. Until this evidence is available veterinary surgeons should consider that the current literature, although low quality suggests that extirpation appears to be a palliative treatment with recurrence invariably occurring following the procedure. Deep excision of the lesion may lead to a potential resolution however there is a moderate rate of long-term recurrence alongside the occurrence of novel lesions.

The aetiology of paw pad corns is currently poorly understood. Suggested causes include; chronic mechanical trauma or pressure, foreign bodies, scar tissue, deficiencies in the fatty layer in the pad and papillomavirus (Guilliard et al., 2010). In one study, canine papillomavirus was isolated from corn lesions in two Greyhounds 
(Anis et al., 2016). However, Balara et al. (2009a) found no evidence of papillomavirus on immunohistochemistry staining in six Greyhounds, but 3/5 dogs which were not Greyhounds were positive for papillomavirus. Given the paucity of reports assessing the involvement of papillomavirus in this condition, it is currently difficult to ascertain its significance. A greater understanding of the aetiology of the condition in Greyhounds may lead to the development of new treatment modalities and therefore better management of the condition. With such high recurrence rates and poor curative treatment options this condition is problematic for the veterinary surgeon.

\section{Methodology Section}

\begin{tabular}{|c|c|}
\hline \multicolumn{2}{|l|}{ Search Strategy } \\
\hline $\begin{array}{r}\text { Databases searched and dates } \\
\text { covered: }\end{array}$ & $\begin{array}{l}\text { CAB Abstracts on OVID interface [1973-2019 Week 45] } \\
\text { PubMed accessed via the NCBI website - Veterinary Science filter } \\
\text { [1910-current] }\end{array}$ \\
\hline Search terms: & $\begin{array}{l}\text { CAB Abstracts: } \\
1 \text { (sighthound* or lurcher* or greyhound* or whippet* or dog or dogs } \\
\text { or canine* or canis).mp. or exp dogs/ or exp canis/ or exp greyhound/ } \\
\text { or exp racing animals/ } \\
2 \text { (corn or corns or hyperkerat* or keratoma* or keratinis* or } \\
\text { keratiniz* or keratos* or "hard pad disease*").mp. or exp } \\
\text { hyperkeratosis/ or exp keratosis/ or exp hyperkeratotic scabies/ or exp } \\
\text { keratinization/ } \\
3 \text { (pedal* or foot or feet or paw* or digit* or heel* or sole* or } \\
\text { footpad* or pad*).mp. or exp feet/ or exp digits/ or exp footpads/ or } \\
\text { exp soles/ } \\
4 \quad 1 \text { and } 2 \text { and } 3 \\
\text { PubMed: } \\
\# 1 \text { (sighthound* OR lurcher* OR greyhound* OR whippet* OR dog OR } \\
\text { dogs OR canine* OR canis) } \\
\# 2 \text { (corn OR corns OR hyperkerat* OR keratoma* OR keratinis* OR } \\
\text { keratiniz* OR keratos* OR "hard pad disease*") } \\
\# 3 \text { (pedal* OR foot OR feet OR paw* OR digit* OR heel* OR sole* OR } \\
\text { footpad* OR pad*) } \\
\# 4 \text { \#1 AND \#2 AND \#3 }\end{array}$ \\
\hline Dates searches performed: & 22 Nov 2019 \\
\hline
\end{tabular}

Exclusion / Inclusion Criteria

Exclusion: Not relevant to PICO

Wrong species

Wrong breed

Textbook chapters

Review article with no detail of technique outcome 
Inclusion: Greyhounds or Sighthounds with pedal corns or keratomas

Surgical excision of lesion performed

Extirpation of lesion performed

Outcome and recurrence of lesion reported

\begin{tabular}{|c|c|c|c|c|c|c|c|}
\hline \multicolumn{8}{|c|}{ Search Outcome } \\
\hline Database & $\begin{array}{c}\text { Number of } \\
\text { results }\end{array}$ & $\begin{array}{l}\text { Excluded - } \\
\text { Not } \\
\text { relevant to } \\
\text { PICO } \\
\text { question }\end{array}$ & $\begin{array}{c}\text { Excluded - } \\
\text { Wrong } \\
\text { species }\end{array}$ & $\begin{array}{c}\text { Excluded - } \\
\text { Wrong } \\
\text { breed }\end{array}$ & $\begin{array}{c}\text { Excluded - } \\
\text { Textbook } \\
\text { chapter }\end{array}$ & $\begin{array}{c}\text { Excluded - } \\
\text { Review } \\
\text { article }\end{array}$ & $\begin{array}{c}\text { Total } \\
\text { relevant } \\
\text { papers }\end{array}$ \\
\hline $\begin{array}{l}\mathrm{CAB} \\
\text { Abstracts }\end{array}$ & 186 & 177 & 1 & 1 & 2 & 1 & 4 \\
\hline PubMed & 87 & 84 & 0 & 0 & 0 & 0 & 3 \\
\hline \multicolumn{7}{|c|}{ Total relevant papers when duplicates removed } & 5 \\
\hline
\end{tabular}

\section{CONFLICT OF INTEREST}

The author declares no conflicts of interest.

\section{REFERENCES}

1. Anis, E.A., Frank, L.A., Francisco R. \& Kania, S.A. (2016). 'Identification of canine papillomavirus by PCR in Greyhound dogs'. PeerJ 4:e2744. DOI: https://doi.org/10.7717/peerj.2744

2. Balara, J.M., McCarthy, R.J., Kiupel, M., Buote, M.A., Wise, A.G. \& Maes, R.K. (2009a). 'Clinical, histologic, and immunohistochemical characterization of wart-like lesions on the paw pads of dogs: 24 cases (2000-2007).' Journal of the American Veterinary Medical Association 234(12), p. 1555-1558. DOI: https://doi.org/10.2460/javma.234.12.1555

3. Balara, J.M., McCarthy, R.J. \& Buote, M.A. (2009b). 'Comments on study of paw pad lesions in dogs.' Journal of the American Veterinary Medical Association 235(6), p. 657-659. DOI: https://doi.org/10.2460/javma.235.6.620

4. Görtz, K., Rooster, H., Chiers, K., Kramer, M. \& Declerq, J. (2003). 'Digital hyperkeratosis as a cause of severe lameness in two Whippets and a Greyhound.' Kleintierpraxis 48 p. 435-439.

5. Guilliard, M.J., Segboer, I. \& Shearer, D.H. (2010). 'Corns in dogs; signalment, possible aetiology and response to surgical treatment. .' Journal of Small Animal Practice 51(3), p. 162-168.

DOI: https://doi.org/10.1111/j.1748-5827.2010.00892.x

6. Macherey, C.L. \& Feeman, W.E. (2006). 'Using a dental root elevator to remove footpad corns in dogs: two practitioners' experience.' Veterinary Medicine 101 p. 778-781. 


\section{EVIIDEFeE

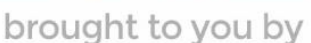 \\ RCVS KNOWLEDGE}

\section{Intellectual Property Rights}

Authors of Knowledge Summaries submitted to RCVS Knowledge for publication will retain copyright in their work, and will be required to grant RCVS Knowledge a non-exclusive license of the rights of copyright in the materials including but not limited to the right to publish, re-

publish, transmit, sell, distribute and otherwise use the materials in all languages and all media throughout the world, and to license or permit others to do so.

\section{Disclaimer}

Knowledge Summaries are a peer-reviewed article type which aims to answer a clinical question based on the best available current evidence. It does not override the responsibility

of the practitioner. Informed decisions should be made by considering such factors as individual clinical expertise and judgement along with patient's circumstances and owners' values. Knowledge Summaries are a resource to help inform and any opinions expressed within the Knowledge Summaries are the author's own and do not necessarily reflect the view of the RCVS Knowledge. Authors are responsible for the accuracy of the content. While the

Editor and Publisher believe that all content herein are in accord with current recommendations and practice at the time of publication, they accept no legal responsibility

for any errors or omissions, and make no warranty, express or implied, with respect to material contained within.

For further information please refer to our Terms of Use.

RCVS Knowledge is the independent charity associated with the Royal College of Veterinary Surgeons (RCVS). Our ambition is to become a global intermediary for evidence based veterinary knowledge by providing access to information that is of immediate value to practicing veterinary professionals and directly contributes to evidence based clinical decision-making.

https://www.veterinaryevidence.org/

RCVS Knowledge is a registered Charity No. 230886.

Registered as a Company limited by guarantee in England and Wales No. 598443.

Registered Office: Belgravia House, 62-64 Horseferry Road, London SW1P 2AF

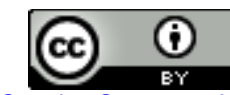

This work is licensed under a Creative Commons Attribution 4.0 International License 